v ruštině (Резюме, s. 193-198), v polštině (Streszczenie, 199-203), rozsáhlý seznam literatury (Literatura, s. 205-216) a rejstř́k v práci citovaných jmen lingvistů (Jmenný rejstřík, s. 217-218).

Práce představuje analýzu morfologicky nezformovaných lexikálních jednotek, které plní vůči řídícímu členu ve větě determinační (atributivní) funkci. Lexikální jednotky disponující touto vlastností jsou nazývány termínem „analytické adjektivum“. Dané kategorii neohebných komponentů adjektivní povahy je věnována pozornost především v ruské jazykovědě více než půl století, avšak nové podněty pro další výzkum přinesla expanze cizích komponentů adjektivní povahy (převážně anglického původu). Nové vývojové tendence projevující se zejména v oblasti lexika a slovotvorby lze sledovat od konce minulého století ve všech slovanských jazycích. Vzhledem $\mathrm{k}$ sílícímu procesu internacionalizace a rostoucím vlivům analytismu a aglutinace na flektivní povahu současných slovanských jazyků představují tzv. analytická adjektiva, zejména tzv. analytická adjektiva širokého pojetí, aktivní slovotvornou bázi.

Odborný př́nos posuzované monografie lze spatřovat ve dvou rovinách, a to jak $\mathrm{v}$ rovině teoretické, tak i v rovině praktické. Její výsledky mohou být využity jako zdroj materiálu a poznatků pro další vývoj v této oblasti jazykového výzkumu.

Aleš Brandner

\title{
Literatura:
}

PLESNÍK, L.: Typologická charakteristika tzv. analytických adjektiv (na príkladovém materiálu ruštiny, češtiny a polštiny). Ostrava: Ostravská univerzita, 2019, $218 \mathrm{~s}$. ISBN 978-80-7599-095-2.

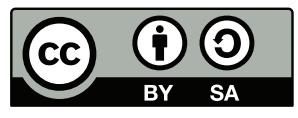

Toto dílo Ize užít v souladu s licenčními podmínkami Creative Commons BY-SA 4.0 International (<https:// creativecommons.org/licenses/by-sa/4.0/legalcode>). Uvedené se nevztahuje na díla či prvky (např. obrazovou či fotografickou dokumentaci), které jsou v díle užity na základě smluvní licence nebo výjimky či omezení príslušných práv.

\section{História a kultúra očami pamiatok}

CINGEROVÁ, N. - DULEBOVÁ, I. - JALOVÁ, K.: Historické a kultúrne pamiatky Ruska. Bratislava: Stimul, 2017. ISBN 978-80-8127-248-6.

Každý, kto chce bližšie spoznat nejaký národ, musí najprv pochopit jeho kultúru. K neoddelitelnej časti kultúry patria aj samotné architektonické pamiatky. Každá 
stavba v sebe totiž ukrýva velkú čast̉ histórie a môže nám vela povedat’ o tom-ktorom národe, o jeho tradíciách, náboženstve, umení, či jeho vývoji v porovnaní s ostatným svetom. K lepšiemu pochopeniu vývinu ruských pamiatok nám môže dopomôct’ aj vysokoškolská učebnica, ktorá vznikla primárne ako doplnkový materiál k výučbe predmetu Kultúrne regióny Ruska $\mathrm{v}$ cestovnom ruchu. Tento heslár $\mathrm{s}$ názvom „Historické a kultúrne pamiatky Ruska“ vyšiel v rámci riešenia grantového projektu KEGA 052UK-4/2018. Zostavili ho členky Katedry rusistiky a východoeurópskych štúdií Univerzity Komenského v Bratislave - doc. Mgr. Nina Cingerová, PhD. a doc. Mgr. Irina Dulebová, PhD., v spolupráci s doktorandkou Mgr. Katarínou Jalovou.

Jeho cielom je, podla slov autoriek, „priblížit študentom rusistiky klúčové pamiatky Ruskej federácie a zasadit ich do politického, spoločenského a kultúrneho kontextu“ (s. 3). Velmi pozitívne možno hodnotit spôsob, ktorý si autorky zvolili pri zostavení tejto publikácie. Okrem základných informácií o tom, kde sa konkrétna pamiatka nachádza, či stručného oboznámenia s okolnostami jej vzniku, sa autorky snažili tieto heslá doplnit aj o zaujímavosti, ktoré sa v súvislosti s danou pamiatkou tradujú. Práve túto skutočnost̉ považujeme za obzvlášt prínosnú, nakolko je daná publikácia určená predovšetkým študentom, ktorí si, podla nášho názoru, najlepšie osvojujú poznatky práve vdaka rôznym neobyčajným príbehom.

Je tiež potrebné poznamenat', že zostavovatel'ky heslára upriamujú svoju pozornost’ len na niektoré pamiatky, nachádzajúce sa na území Ruska, nakolko by vzhladom na rozlahlost tejto krajiny a jej bohatú históriu bolo úplné zmapovanie všetkých pamiatok pomerne komplikované a podstatne by navýšilo rozsah publikácie. Autorky preto vybrali tie najznámejšie či najvýznamnejšie pamiatky z každej oblasti (náboženskej, spoločenskej alebo kultúrnej). Taktiež možno vyzdvihnút logické usporiadanie heslára, nakolko sú všetky vybrané pamätihodnosti abecedne zoradené a rozdelené do tematických celkov, podla ich spoločenského využitia. Pri každej reálii je uvedený aj jej názov v ruskom jazyku.

Heslár pozostáva zo šestnástich tematických celkov. Pričom prvá kapitola je venovaná budhistickým chrámom, ktoré sa na území Ruska zachovali a dodnes splñajú svoj účel. Druhá čast je zameraná na samotné Červené námestie, teda na pamiatky, ktoré ho obklopujú a dodávajú mu charakteristický kolorit. Tretia kapitola zahŕňa najvýznamnejšie ruské divadlá, $\mathrm{z}$ ktorých mnohé možno považovat za klúčové, a to nie len z hladiska ruských dejín umenia. Štvrtú skupinu pamiatok tvoria galérie, obsahujúce významné diela nielen ruského, ale aj svetového umenia. Piata čast’ je venovaná „iným lokalitám“, ku ktorým autorky zaradili rôzne archeologické náleziská, či krasovú jaskyňu s dodnes zachovanými pravekými jaskynnými malbami. Šiesta kapitola predstavuje kláštory. No kedže ich je na území Ruska nespočetné množstvo, ide o jednu z najobjemnejších častí publikácie. Ďalší celok tvoria 
„kremle“1 a pevnosti, ktorým sa ruských dejinách prikladal velký význam, pretože slúžili na obranu územia pred nepriatel’mi. Ôsma kapitola prezentuje literárne múzeá. Aj v tomto prípade ide o velmi rozsiahlu čast̉ ruskej kultúry, kedže ruská literatúra predstavuje široké spektrum významných autorov, a takmer každému z nich je venované nejaké múzeum. Je preto pochopitelné, že spomedzi velkého množstva múzeí museli autorky vyberat naozaj velmi dôsledne. Vo výsledku je potrebné ocenit ich reprezentatívny výber, pretože ide o múzeá, venované práve tým autorom, ktorí v najväčšej miere ovplyvnili smerovanie ruskej či svetovej literatúry. Deviata čast̉ je zasvätená mešitám, ktoré majú v Rusku „slušné“ zastúpenie. Desiatou, rozsiahlejšou kapitolou sú múzeá, predstavujúce a zastrešujúce nie len ruský folklór a tradičné ludové umenie, ale aj také, ktoré sú politicky či menšinovo zamerané. $V$ tejto časti možno nájst’ skanzeny, pamiatkové rezervácie, ale aj Štátne historické múzeum, ktoré je zároveň najstarším muzeologickým centrom krajiny, a tiež Štátnu Ermitáž - najväčšie ruské múzeum, a zároveň jedno z najväčších svetových umeleckých a kultúrno-historických múzeí. Predmetom jedenástej kapitoly sú paláce, dvanástej - pietne miesta. Ďalšiu skupinu hesiel predstavujú početné pravoslávne chrámy, nakolko pravoslávna cirkev má v Rusku v rámci náboženstva najväčšie zastúpenie. Záverečné celky pamiatok sú zoskupené podla synagóg a usadlostí. Celý heslár uzatvára Zlatý okruh Ruska. Ide o turistickú trasu, ktorá pozostáva z ôsmych miest, a to z Sergijev Posad, Pereslavl' Zalesskij, Rostov, Jaroslavl, Kostroma, Ivanovo, Suzdal a Vladimir.

Ako teda vyplýva z uvedeného, prezentovaná publikácia je skutočne obohacujúca a vel'mi kvalitne vypracovaná. Autorky si dali naozaj záležat na tom, aby čitatela oboznámili so všetkými klúčovými faktami o jednotlivých pamiatkach. Možno konštatovat', že predkladaný heslár je bezpochyby vhodnou a užitočnou pomôckou pre študentov - rusistov, či v oblasti cestovného ruchu, ale zaujme aj milovníkov ruských dejín a kultúry.

Zina Špačeková

\section{Literatúra:}

CINGEROVÁ, N. - DULEBOVÁ, I. - JALOVÁ, K.: Historické a kultúrne pamiatky Ruska. Bratislava: Stimul, 2017. ISBN 978-80-8127-248-6.

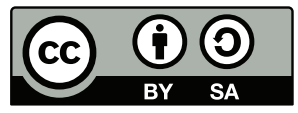

This work can be used in accordance with the Creative Commons BY-SA 4.0 International license terms and conditions (<https://creativecommons.org/licenses/by-sa/4.0/legalcode>). This does not apply to works or elements (such as images or photographs) that are used in the work under a contractual license or exception or limitation to relevant rights.

1 Hoci má v slovenskom jazyku slovo „Kremel“ iba tvar jednotného čísla a spája sa predovšetkým so sídlom ruského prezidenta, my sme zámerne použili formu množného čísla. Pretože v Rusku slovo „kremel“ predstavuje historickú stavbu, opevnenie, ktoré v minulosti chránilo územie, pred vonkajšími nepriatelmi a takýchto „opevnení“ je na území Ruska niekolko. 